\title{
Reinterpretation and Reconstruction of the Folktale Jaka Tarub into Akhudiat's Play Jaka Tarub: A New Historicist Reading
}

\section{M. Rahayu, A. Priyatna, and R. Budhyono}

Faculty of Cultural Sciences, Padjadjaran University, Jalan Raya Bandung Sumedang KM. 21, Sumedang, West Java 45363, Indonesia

\section{Abstract}

The article examines the transformation of 'Jaka Tarub', a folktale contained in Babad Tanah Jawi, into the play Jaka Tarub by Akhudiat. Jaka Tarub by Akhudiat is a two-act play that is parodic in style. The play won the 1974 Jakarta Arts Council Playwriting Competition. The aim of the article is to study how the tale is interpreted and reconstructed into Indonesian contemporary literature. The transformation of the

Corresponding Author:

L. M. Rahayu

lina.meilinawati@unpad.ac.id

Received: 6 April 2018

Accepted: 3 May 2018

Published: 26 July 2018

Publishing services provided by Knowledge $\mathrm{E}$

(c) L. M. Rahayu et al. This article is distributed under the terms of the Creative Commons

Attribution License, which permits unrestricted use and redistribution provided that the original author and source are credited.

Selection and Peer-review under the responsibility of the ISLLE 2017 Conference Committee. tale is analyzed from a new historicist perspective. The analysis suggests that the history of a nation can be read through its literature since New Historicism sees that texts and history are always, inevitably, interrelated. Based on such a perspective, there is no longer such a thing as a single absolute 'historical reality'. Instead, there are always different versions and perspectives of history. Akhudiat's reinterpretation and reconstruction of the folktale represent Indonesia in the 1970s. Seen in this light, an Indonesian literary text that reflects history can be regarded as another version of history. Thus, New Historicism offers an appropriate approach to study such a literary text because it is through a New Historicist approach to reading that realities unwritten in mainstream texts of history become accessible to the reader or audience.

\section{Keywords: folktale, reconstruction, reinterpretation, transformation}

\section{Introduction}

Jaka Tarub is a folktale from Central Java. The tale tells the story of a dashing, stout young man named Jaka Tarub, who is believed to possess some kind of mighty power. He often sets out to hunt animals in a forest surrounding a sacred mountain. One day, by accident, he arrives at a lake hidden somewhere in the depth of the forest. At that time, seven angels happen to have just descended from their abode and are bathing in the lake. The young man watches them from a distance. Charmed by the beauty 
of the angels, Jaka Tarub takes a shawl that belongs to one of the angels. After they have finished bathing in the lake, the angels dress before ascending to their abode. Unable to find her shawl, one of the angels cannot return to her dwelling place. She is left alone in the forest by the other six angels. Jaka Tarub then comes out from where he has been hiding and comes to the rescue. Because the day is getting dark, Nawang Wulan has no choice but to follow Jaka Tarub to his home.

To cut the story short, Jaka Tarub and Nawang Wulan get married and soon a daughter is born. Before marrying Jaka Tarub, Nawang Wulan has made a deal with Jaka Tarub that he should not by any means ask her any question about how she does things after she becomes his wife. Nawang Wulan has a secret. Every day, she cooks only one single rice grain. However, with the power she has, the grain multiplies and is enough for the whole family to eat. Jaka Tarub is curious about this. One day, he secretly opens the lid of the rice steamer, which suddenly broke Nawang Wulan's mighty power. Ever since this incident, Nawang Wulan has to cook rice ordinarily, like all other women do. As a result, they soon are out of rice stock in their barn. When most of the rice had been cooked, something is revealed. Nawang Wulan finally finds out that her shawl has been hidden at the bottom of the rice stock in the barn. Nawang Wulan is very upset to discover that it is her husband who has been hiding her shawl. She threatens to leave Jaka Tarub, however, he begs her not to go. Nonetheless, Nawang Wulan is not to be persuaded and eventually leaves him.

The tale of Jaka Tarub has many versions, but the standard version, which is also written in Babad Tonah Jawi, follows the aforementioned plot. The story of Jaka Tarub is one of the folktales that circulate in the Java Land. The origin of the Jaka Tarub folktale is unknown, generally because folktales are anonymous and the folklores of a particular people are considered as belonging collectively to them. According to Danandjaja [1], such anonymity is due to the fact that the creator had become unknown and all members of the community felt that it belonged to them all.

Elsewhere, Damono [2] argues that in order for literature to function as an effective means of communication, it has to link itself to mythology. In Indonesian literature, a number of writers incorporate mythology into their works. Such writers include Seno Gumira Adjidarma (Wisanggeni), Mangunwijaya (Roro Mendut), Ajip Rosidi (Roro Mendut), Saini K.M. (Ken Arok), Pramudya Ananta Toer (Arok Dedes), Gunawan Muhamad (Tentang Sinterklas), and Sindhunata (Anak Bajang Menggiring Angin). According to Junus [3], literature has the function to affirm mythologies or even modify them. 
It is apparent that there are many literary works that use mythology as their source, thus studies on them are important [4]. With mythologies being widely popular among different communities, one cannot help suspecting that there is some kind of ideology that they attempt to communicate [5]. There are at least two reasons why it is important to study mythology-based literature. The first reason has to do with how an author uses mythology in a piece of work: whether a work alludes to mythology to affirm it or otherwise $[6,7]$. The second reason deals with what ideological aims an author attempts to pursue by incorporating mythology into a work. The study focuses on Jaka Tarub, a play by Akhudiat, which bases itself on the folktale of Jaka Tarub.

\section{Methods}

Budianta [8] delves into the contribution of New Historicism ( $\mathrm{NH}$ ) to the history of literary criticism in the West and what it has to offer to Indonesian literary criticism. There are three questions Budianta attempts to address in her article regarding the criticism that developed in the last two decades of the twentieth century: (i) what does New Historicism contribute?; (ii) does New Historicism offer new possibilities for literary studies and criticism in Indonesia?; and (iii) what are its limitations? In other words, in her article, Budianta elaborates on some aspects of New Historicism.

New Historicism is an approach to literature that highlights the interrelation between a literary text and the social, economic, and political contexts surrounding it. The approach enables literary scholars to examine literary and non-literary texts that represent similar issues.

The aforementioned explanation implies that all texts always represent their time, including literary texts, and, in this case, drama. As Foucault [9] argues, any texts including academic discourses of an age or any forms of representation of an age appear because of the condition of the age. Literature can no longer be viewed as something that is out of any historical context, floating in the air like a foreign, isolated, and separate entity. Literature does not emerge from a void. Neither does it fall from the sky. This is in line with Greenblatt's view [6] that the world portrayed in literature is not an alternative world. It appears in literature as a way to intensify the world in which we live. In studying such interrelation, New Historicism highlights the importance of the political and ideological dimension of cultural products.

Thus, as also suggested by Budianta [8], history, literature, monument, photographs, fashion mode, and money are all part of a system of signs that represent those which 
exist outside them by selecting and arranging signs in the existing system. Thus, constructing Indonesia in a play and comparing it to what is portrayed in non-fictional texts will result in a representation of what Indonesia was like at the time the work was written [10].

\section{Results}

Akhudiat, a national playwright, was actively involved in Bengkel Muda Surabaya, which was very productive in the 70s. Five of the plays that he wrote each won a place in the playwriting competition held by the Jakarta Arts Council (1972-1977). The five award-winning plays by Akhudiat are Graffito (1972), Jaka Tarub (1974), Rumah Tak Berasap Rumah Tak Beratop (1974), Bui (1975) and RE (1977). Thanks to these five plays, Akhudiat received an opportunity to attend the International Writing Program at the University of lowa, USA, in 1975. Led by Akhudiat, the theatre company gained fame because of their kentrung performance, with their contemporary styles of costume and stagecraft. Akhudiat is known for his treatment, which fuses modern and traditional elements in his theatrical performances. The following section discusses the play Jaka Torub, which is the pre-existing folktale of Jaka Tarub.

\subsection{Reinterpretation and reconstruction of the story of Jaka Tarub}

Akhudiat's Jaka Tarub is a two-act play. Act One focuses on Jaka Tarub's identity and his exploits and depicts how Nawang Wulan and other angels rape Jaka Tarub. Act One also presents a series of ridiculous scenes involving the characters. Act Two presents a character named Macan who wants to introduce Nawang Wulan to a film producer. The producer wishes to promote her as an actress; however, Jaka Tarub does not respond well to Nawang Wulan's desire to be an actress. He objects to the idea and plans to take Nawang Wulan away.

The opening of the play may be shocking to those who are already familiar with the folktale version. In the play, Jaka Tarub is not portrayed as the character popularly known; he is a cowboy. This is also the case for Nawang Wulan. Most people may imagine Nawang Wulan as a tender, beautiful woman who cannot find her shawl after bathing in a lake. In this play, however, Nawang Wulan is an ambitious woman who wants to pursue a career as a model and actress. The following extracts describe Jaka Tarub's and Nawang Wulan's appearance: 
JAKA TARUB : (Enters. Dressed in an up-to-date fashion like other today's young men, carrying a traveler's backpack on his back).

NAWANG WULAN : (Enters from left. Dressed in a backless overall dress. Carrying a travel bag, ready to travel).

The aforementioned description portrays how both characters look like the young people of today. The readers are told that Jaka Tarub is deliberately awakened by the dalang. Besides, Jaka Tarub himself has grown tired of living in a museum. When the dalang calls him to the scene, Jaka Tarub feels very happy, as reflected in the following text:

JAKA TARUB : I was dying in the museum, Old Man. You can't imagine how exalted I was when you awoke me from my state of wayang-like deadness. I was able to free myself from the squeeze of those thick, dusty books and jump through the back window and run through the bushes.

The tale of Jaka Tarub begins with the missing shawl that belongs to one of the angels. The angel, Nawang Wulan, who has lost her shawl, agrees to follow Jaka Tarub because her companions have left her and went to heaven. Nawang Wulan accepts Jaka Tarub's proposal to marry her. However, in Akhudiat's play, it is the angel who chases after Jaka Tarub and rapes him. The dalang, who narrates the plot and is involved in the story, becomes confused because the plot deviates from the original. The author puts the character Jaka Tarub in a 'contemporary' situation.

Jaka Tarub \& Nawang Wulan are engaged in a stunning silat \& judo fight act which ends with a handshake, lip kiss, cheek kiss, hug, and dance to a slow up to an upbeat rock dance music.

Music. From War to Dance music.

In the play Jaka Tarub, Akhudiat not only offers the reader entertainment, but he also presents the result of his deep contemplation concerning the social and cultural problems during the period when it was written. The characters and events in the play are modified in such a way because there is a concept that the author needs to convey. The idea behind such changes is discussed in the following section. 


\subsection{The play Jaka Tarub:}

\section{A protest against the social condition in the $70 \mathrm{~s}$}

A creative process in which a classical tale or myth is used as a basis for a new work is common to writers all over the world. The myth is often alluded to in a literary work in order to convey a certain idea or concept without the complicated burden of explaining the details, as the myth is already well known. For example, the folktale Roro Mendut is alluded to by at least two renowned Indonesian literary figures, Ajip Rosidi and J.B. Mangunwijaya. The classic tale of true and eternal love is modified and set in the period during which each author was writing. Mangunwijaya's work, for example, unlike the original tale, is imbued with aspects of feminism and the theme of fighting for justice.

The rise of the New Order brought a new hope for a better life. However, even since the early days of the New Order, social injustice was strongly felt despite the fall of the preceding Old Order. The social gap grew even wider. Drama is a form of art that can be written with an intention to speak directly to an audience in the face of a difficult predicament. Such tendency is apparent in most plays written in the period. The issues such as power, politics and social injustice were readily available as a fertile source of inspiration for Indonesian playwrights.

In plays written in the 70s, such a tendency is shown in various ways. In their works, playwrights took recourse to satire, mockery, and sarcasm to convey their message and remind the reader/audience that social gap and injustice were real. Indeed, issues of power, politics, social gap and their consequences were the main ingredients in Akhudiat's Jaka Tarub. In the play, Akhudiat resurrects a classical character (Jaka Tarub) and places him in the hustle and bustle of daily life. Sharp criticism is delivered not only through dialogues but also through Dalang's chorus:

DALANG : Masya Allah, God has willed ... (Meditating)

All demons lurking

In the tunnel of Priok

And in the tunnels in all headlands

Begone or thou shalt reincarnate

As humans

Labour honestly as civil servants

Thou art better paid than this poor Kentrung Dalang. 
The song sung by the Dalang satirizes the 'demons' gripping Tanjung Priok, a large port where goods come in and out of the country-a strategic place where public officials ('demons') impose levies. The public is aware of such corrupt practice.

Indonesia's development policy toward the end of the New Order put a heavy emphasis on the economic sector. Economic development was then focused on industries, agriculture, and improvement of human resources to support economic growth. However, PELITA VI (The $6^{\text {th }}$ Five-Year Development Program), which anticipated that Indonesia would 'take off' and reach a better stage, resulted in failure. Indonesia was hit by a harsh economic crisis in 1997. It began as a monetary crisis, then an economic crisis, and subsequently escalated into a crisis of trust in the government. Corruption, collusion, and nepotism were everywhere. The fruit of development was reaped by only a petty percentage of the entire population. Development was centralized, creating disparities. In figures, the economy was growing, but economic development was in a fragile state.

Such conditions became the object of satire in Jaka Tarub. Degradation occurred in all aspects of people's lives because of the government's policies. For example, Indonesia had to import rice, and the rice that was affordable to poor people was of a bad quality, as satirized in the following dialogue:

JAKA TARUB : I have to know. My stomach has been protesting for quite long why you cook rice that smells like rice bran.

NAWANG WULAN : Oh, it's imported. Remnants of horse feed.

JAKA TARUB : Do we people belong to a class lower than equus?

NAWANG WULAN : Ask the big shots in Tanjung Priok.

The author, Akhudiat, deliberately admits that his play is a parody, a work of literature that copies and at the same time deviates from the original. The aim of a parody is not only to amuse but also to convey satire, sometimes in a harsh way. The satire in the play is directed at the government and its policies. The following is an example of satire against the government for having huge amounts of foreign debts:

CHORUS : (Singing)

From west to east

Working on miniature projects

CHORUS : From south to north

Planting rice to yield debts 
Thus, by 'twisting' the folktale of Jaka Tarub, Akhudiat conveys a new way to view the diverse social and cultural problems during the time of writing. Akhudiat borrows from a folktale and at the same time explores the traditional theater of Kentrung as his means to communicate the social climate.

\section{Conclusion}

Ideas such as Akhudiat's are important to contextualize a classical tale of modern life. Furthermore, as exemplified by Akhudiat, contemporary writers can use myths as a vehicle for their ideologies. The characters and events in the original texts can be modified in such a way that serves their purpose. Akhudiat presents his idea and reaction against the social condition by borrowing the tale of Jaka Tarub, which was extremely popular. The tale is modified to convey his ideology. Thus, reading a literary text that reflects history is more or less reading another version of history.

\section{References}

[1] Danandjaja, J. (2002). Folklor Indonesia: Ilmu Gosip, Dongeng, Dan Lain-Lain [Folklor Indonesia: Science of Gossip, Fairy Tale, and Others]. Jakarta: Grafiti.

[2] Damono, S. D. (1999). Politik, Ideologi, Dan Sastra Hibrida [Politics, Ideology, and Hybrid Literature]. Jakarta: Pustaka Firdaus.

[3] Junus, U. (1981). Mitos dan Komunikasi [Myths and Communication]. Jakarta: Penerbit Sinar Нагараn.

[4] Soemanto, B. (2001). Jagad Teater [Theater World]. Yogyakarta: Media Pressindo.

[5] Payne, M. and Barbera, J. R. (2013). A Dictionary of Cultural and Critical Theory. New Jersey: John Wiley \& Sons.

[6] Greenblatt, S. (1989). Toward a Poetics of Culture in the New Historicism. London: Routledge.

[7] Kartodirdjo, S. (1982). Pemikiran dan Perkembangan Historiografi Indonesia: Suatu Alternatif [Thought and Development of Indonesian Historiography: An Alternative]. Jakarta: Gramedia.

[8] Budianta, M. (2006). Budaya, sejarah, dan pasar: New historicism dalam perkembangan kritik sastra [Culture, history, and market: New historicism in the development of literary criticism]. Jurnal Susastra, vol. 3, pp. 1-19. 
[9] Foucault, M. (2011). Pengetahuan dan Metode: Karya-Karya Penting Foucault [Knowledge and Methods: Important Works of Foucault]. Yogyakarta: Jalosutro.

[10] Ricklefs, M. C. (2008). Sejarah Indonesia Modern [History of Modern Indonesia]. Yogyakarta: UGM Press. 